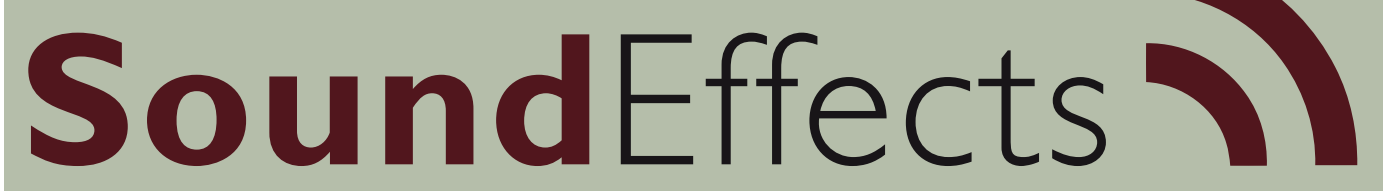

An Interdisciplinary Journal of Sound and Sound Experience

\title{
Ian Stevenson
}

\section{De Quincey's acoustemology}

\author{
Dr. lan Stevenson \\ School og Humanities and Communication Arts \\ University of Western Sydney, Australia \\ i.stevenson@uws.edu.au
}

www.soundeffects.dk 


\begin{abstract}
This article reports on a reading of aspects of sound and knowledge in the writings of English essayist Thomas de Quincey (1785-1859). The article develops the concept of the sonic effect as it emerges in de Quincey's sonic aesthetics. This is supported by a summary of de Quincey's apparent critique of Kantian understanding and judgement as it relates to sound. The historical development of notions of effect contemporary to de Quincey is explored, and the parallels between his use of sound and subsequent sonic design in crime fiction and the development of audiovisual drama in general are considered. Three key sound effects: the knock, the sigh and the solemn wind are developed and analysed by de Quincey and are shown to be part of a unique de Quincian acoustemology. The research in this article formed the initial phase of a larger practice-based research project culminating in a new sound design for a hybrid performance-installation work.
\end{abstract}

\title{
Preamble
}

This article reports on a reading of aspects of sound and knowledge in the writings of English essayist Thomas de Quincey (1785-1859). During the research phase for the sound design of a new hybrid performance-installation work based on selected texts by de Quincey (de Quincey Co., 2009), I was struck by his novel use of sound. This new work drew on text material from a selection of de Quincey's best-known works. These included the autobiographical 'Confessions of an English Opium Eater', first published in 1821, and 'Suspiria de Profundis', a sequel to it, published in 1845. These works, characterised by de Quincey's discursive meanderings, describe the preconditions for opium addiction, and the hallucinatory activity of the mind under its influence. A second group of source texts includes a collection of essays on the subject of murder: the two pseudo-lectures 'On Murder Considered as one of the Fine Arts', published in 1827 and 1839 respectively, and a postscript to these entitled 'The Avenger', published in 1854, and a short article 'On the Knocking at the Gate in Macbeth' from 1823. During the recording and editing of the material I was guided or influenced by my preliminary readings of de Quincey with an ear for his use of sound description and sound images. My reading of de Quincey was not so much an attempt to understand his use of sound, as it reflected a broader contemporary sonic ecology, as might be found in an example of sound studies such as Folkerth's broad-ranging analysis of sound in Shakespeare (2002). Rather, I paid attention to de Quincey's development of sound as a literary device within the context of his unique critique of human knowledge, reasoning and experience as seemed appropriate to the themes of the creative project of which this reading was a central part. 


\section{Introducing the sound effect}

Like many of his precursors in the English romantic movement, and particularly his mentors Coleridge and Wordsworth (Lindop, 1985, p. viii), de Quincey was sensitive to auditory experience and exhibited the tendency to use sound as a symbolic device. He also used sound as an effective dramatic and narrative device adding sensory realism to engage the reader. But more importantly, de Quincey was interested in the role of sound in the production of a range of literary effects, which he draws both from the context of European literature and by transforming his own experience into literary material. I argue here that de Quincey's poetics represent an exemplar for the working out of the concept of the sonic effect as introduced by Jean-François Augoyard and Henry Torgue $(2005$, p. 9). It is the complex relationship between sound effects and the sonic event-effects or sense-effects with which they are correlated that is the focus of this article. The paradigmatic concept of the sonic effect and its definition in terms of contexts, relations and the discourse of various disciplinary domains, developed by Augoyard and his colleagues, draw on the ontological system of Gilles Deleuze in which the entities we encounter are both products of and producers of sense events. This bivalent or multivalent process is named as effect in Deleuze's Difference and Repetition (1968/1994) and The Logic of Sense (1969/2004). Accordingly, my reading of de Quincey and my exploration of the effect is drawn together from a diverse bricolage of philosophical, literary and scientific perspectives from the history of Western thought with which the effect can be illuminated. This article explores the usefulness of the concept of the sonic effect in producing a reading of an author such as de Quincey.

\section{Examples of sound effects in de Quincey}

Two of the selected essays, 'On the Knocking at the Gate in Macbeth' and 'Suspiria de Profundis' ('Sigh from the Depths'), take sound effects as their central conceit. The knock and the sigh echo or reverberate throughout de Quincey's writing. ${ }^{1}$ For example, the knocking effect explicitly links the two essays 'On the Knocking at the Gate in Macbeth' and 'On Murder Considered as one of the Fine Arts' (1985/1823, p. 82), and de Quincey uses this recurrence of the effect as a means of critically analysing its use within Shakespeare's dramatic tragedy Macbeth.

De Quincey's essay style is a dense mix of literary allusion and re-worked memoir, and the sounds presented by de Quincey exist in this particular context. However, within this frame de Quincey develops what might be considered an acoustemology (Feld, 2003) or theory of knowing through sound. Whereas in Feld's ethnographic research sound is encountered and produced within an environmental and social 
ecology, de Quincey produces and encounters sound in memory and in the literary context of the intellect.

An example of his observations on sound arises in the context of a typically cursory philosophy of musical effects developed in the context of experiments with opium. De Quincey claims that 'music is an intellectual or sensual pleasure according to the temperament of him who hears it' (1985/1821, p. 45). He goes on to make the assertion, apparently influenced by his reading of Kant's critiques of reason and judgement, ${ }^{2}$ that 'the mistake of most people is to suppose that it is by the ear they communicate with music, and therefore that they are purely passive to its effects. But this is not so: it is by the reaction of the mind on the notices of the ear, (the matter coming by the senses, the form from the mind) that the pleasure is constructed'. For de Quincey, opium's stimulation of the intellectual faculty facilitates his ability 'to construct out of the raw material of organic sound an elaborate intellectual pleasure'. The nature of this 'intellectual pleasure' is not exactly clear as it is described in the subsequent characteristically labyrinthine circumlocution. However, de Quincey states categorically, ${ }^{3}$ that, for him, the pleasure is not derived from 'a class of ideas [...] that have a language of representative feelings'. Under the influence of opium an 'elaborate harmony, displayed before me, as in a piece of arras work, the whole of my past life - not, as if recalled by an act of memory, but as if present and incarnated in the music: no longer painful to dwell upon: but the details of its incidents removed, or blended in some hazy abstraction; and its passions exulted, spiritualized, and sublimed'. This is surely a drug-induced reverie or phonotonie (Augoyard \& Torgue, 2005, p. 86) of the highest order, and de Quincey amusingly defuses its pretensions to being a grand theory of music by qualifying that 'all this was to be had for five shillings' (1985/1821, pp. 45-46). However it is apparent from his description that de Quincey is not referring to a simple case of anamnesis - "in which a past situation or atmosphere is brought back to the listener's consciousness, provoked by a particular signal or sonic context' (Torgue, 2005, p. 21) - but to a more complex psychological reframing of memory brought about by the effects of opium. Whether this image is constructed for literary effect or not, his Kantian claims for musical aesthetics are striking. In de Quincey's analysis the audience is not the passive recipient of the expressive content of musical sound, rather he/she is active in the construction of aesthetic judgements in which the understanding provides a form by which the sensory sonic matter may be transformed into its full aesthetic effect.

This reflection on the role of the understanding in apprehending sound is an important first step in exploring de Quincey's use of sound. Beyond this, sound features in the 'Confessions' particularly as a defining element in the apocalyptic dreams that de Quincey relates ${ }^{4}$ as a frightening symptom of opium use. 


\section{De Quincey, the understanding and the sound effect}

It is useful to consider de Quincey's use of the term effect. At the time de Quincey was writing the word effect was being employed for the first time in a range of innovative ways. In the field of science a range of new principles of relation between forces, matter and its behaviour were being introduced (OED "effect, n.," 2011, n. 1. d). De Quincey's interest in science and its contemporary debates is evident in the subject matter of his essays. It is possible he was aware of the published works of Faraday, Kelvin, Ampere, Ohm and others, cataloguing a range of new effects which during the middle and latter part of the nineteenth century became known by their discoverers' names (Bernoulli effect 1738, Coriolis effect 1835, Doppler effect 1842, Faraday effect 1845 , Kelvin effect 1852, Gibbs-Marangoni effect 1855). ${ }^{5}$ Furthermore, the OED notes the introduction in the early nineteenth century of two uses of the term, one referring to 'the impression produced on a beholder, hearer, or reader [...] especially by a work of art or literature [which is designed] for effect: for the sake of creating a telling impression on the minds of spectators or hearers' (emphasis added) and is 'in principle distinguished from' a second sense 'referring to the physical phenomena themselves rather than the way they are perceived, but in practice [the dictionary is careful to point out] there is much overlap'. The physical phenomena are characterised by 'a (pleasing or remarkable) combination of colour, form, etc., in design and the visual arts [, and also] in extended use, with reference to music' ("effect, n.," 2011, n. 9.a and 4.b, respectively). And yet another distinct usage arising in the early nineteenth century refers to 'a visual or acoustic device used to convey atmosphere or the illusion of reality in the production of [theatrical] plays'. With special uses: sound-effect, special-effect and stage-effect ("effect, n.," 2011, 4. c.). This is not to assert that theatrical sound effects were invented in the nineteenth century or even that a more subtle understanding of sound's creative possibilities arose at this time (for example, see Folkerth's description of Shakespeare's manipulation of the polysemic possibilities of sound (2002, p. 33)), but that perhaps a more functional or instrumental approach to sound effects was beginning to be written about and documented. The adaptation of these terms seems to indicate a general shift from a world view of material causes to a more subtle understanding of influences and correlations and the possibilities of bringing these under control both in the arts and sciences.

De Quincey's assertions regarding the requirement of the combination of sensation (intuition in Kant's terminology), sensibility and concepts as the basis for aesthetic judgement are taken up again in more detail in the essay 'On the Knocking at the Gate in Macbeth', and in 'Suspiria de Profundis' we see a more thorough working-out of the sound effect. The first of many discursions in 'The Knocking' presents a critique of the understanding as an unreliable faculty of the mind when relied on 
too heavily. At this point it might be useful to outline Kant's epistemological terminology which is apparently the object of de Quincey's interest. In the Critique of Pure Reason, in the section entitled 'Transcendental Aesthetic' (1787/1929, A19/B32), Kant provides a succinct summary (I have added emphasis to the key terms):

In whatever manner and by whatever means a mode of knowledge may relate to objects, intuition is that through which it is in immediate relation to them, and from which all thought gains its material. But intuition takes place only in so far as the object is given to us. This again is only possible, to man at least, in so far as the mind is affected in a certain way. The capacity (receptivity) for receiving representations through the mode in which we are affected by objects, is entitled sensibility. Objects are given to us by means of sensibility, and it alone yields us intuitions, they are thought through the understanding, and from the understanding arise concepts.

De Quincey 'exhorts the reader never to pay any attention to his understanding when it stands in opposition to any other faculty of his mind' (1985/1823, p. 81). Here de Quincey expresses his distrust for the conceptual apparatus of conventional thought, favouring what is given through sensibility. In a perfect example of phenomenological argument, which may have been lifted from the pages of Merleau-Ponty, ${ }^{6}$ de Quincey provides the example of the average person's inability to produce a pictorial representation of perspective, because the concept of horizontal, parallel and perpendicular lines forces his 'understanding to overrule his eyes' and prevents him from making a representation that satisfies his conscious impression of converging lines. And so it is that de Quincey establishes that in the case of 'the knocking at the gate, that succeeds to the murder of Duncan' in Shakespeare's Macbeth, he is in need of some method, perhaps phenomenological/hermeneutic, to help him to understand the effect that 'reflected back upon the murder a peculiar awfulness and a depth of solemnity' from a simple knock. He goes on to complain that 'however obstinately I endeavoured with my understanding to comprehend this, for many years I never could see why it should produce such an effect' (p. 81). Here we have a case of both a sound effect in its theatrical sense and a subjective, sonic effect, hovering on the exterior of a plane or surface of sense. It is the peculiar logic of this effect that de Quincey uncovers or wrestles with in the essay. De Quincey notes that his 'understanding could furnish no reason why the knocking on the gate should produce any effect direct or reflected: in fact, my understanding said positively that it could not produce any effect' (p. 82). ${ }^{7}$

In his development of the theory of the sonic effect, Augoyard (2005, p. 10) relies on the notion of surface effects introduced by Deleuze (1969/2004, pp. 7-16) that characterises the circulation and production of sense in the world of experience. It appears that in this essay de Quincey is moving beyond the limited Kantian correlated ontologies of concepts and objects-as-given to a more expansive and playful relationship between events (such as the knocking) and the effects which either pro- 
duce or fail to produce the sense of such events. This parallel between de Quincey's analysis and description of literary sound effects and Augoyard's conceptual tools for the analysis of urban atmospheres highlights the usefulness of the latter.

\section{The knock, the sigh and the structure of sonic events}

De Quincey finally uncovers the cause or perhaps the sense of the effect, or more accurately, in Deleuze's terminology, the conjugation ${ }^{8}$ of successive effects in a chain or series. The clue for de Quincey comes in the form of news reports of a series of notorious murders in London in 1812: the Williams murders. These become the topic of a series of essays by de Quincey starting with 'On Murder Considered as One of the Fine Arts' in 1827 (2006). These essays themselves become a rich source of sound effects, each one providing a template for subsequent similar effects in audiovisual media (especially in the context of crime thrillers) of the twentieth century. In his explanation of the knocking effect de Quincey compares it to the sigh (another carefully considered sound effect as we shall see) produced by a person regaining consciousness after fainting. This sigh signifies the 'recommencement of suspended life' and it in turn relies for its effect on a preceding silence on which it is superimposed, or as de Quincey explains, the silence relies on the sigh for its meaning to emerge. To clarify (or expand, as is his style), de Quincey uses the example of a silence in a crowd assembled for a funeral and lays on top of this another sound effect, that of the rattling of the wheels of the hearse. In both cases - the sigh and the rattling wheels - these effects mark the end of a 'complete suspension and pause in ordinary human concerns'. However, what is most significant about these effects is that as events they cause the 'full and affecting' apprehension; they 'make known audibly [...] that the pulses of life are beginning to beat again: and the re-establishment of the goings-on of the world in which we live, first makes us profoundly sensible of the awful parenthesis that had suspended them'. The process by which the preceding state of affairs is moved from the sensible unconscious to the understanding whereby a retrospective judgement can be made to 'make known audibly' not that which is presently audible but that state of affairs which has just passed away, is the central acoustemological concern of the essay. This non-sequential (and therefore non-consequential) reframing or transformation of the events, states of affairs and their related or correlated effects or meanings is a repeated device in de Quincey's use of sound effects. ${ }^{9}$

\section{The footstep, the breath and the murderous mind}

The shift in perspective that de Quincey wishes to highlight is central to his (and, as he asserts, Shakespeare's) poetics of murder. De Quincey maintains that the ordi- 
nary perspective on murder is as an effect of 'coarse and vulgar horror' in which sympathy is directed to the victim. We might consider this a sedimented or conventional subjective response, and according to de Quincey 'such an attitude would little suit the purposes of the poet'. With the expedient device of the sound effect he is able to show how, with the 'suspension of ordinary [...] human concerns', the audience or reader is made to apprehend the murderer's affective state. We are able to 'enter into his feelings and [be] made to understand them'. De Quincey shows how affect and states of mind are objectified or actualised and how Shakespeare's drama forces us to 'look into' and have 'sympathy' with Macbeth's 'strife of mind'. This strife of mind is merely a particular actualisation of the independent objectality of 'the murderous mind' which is presumed to be in both Macbeth and his wife. De Quincey asserts that to understand Shakespeare's achievements, which he compares to 'the phenomena of nature', they must 'be studied with the entire submission of our own faculties' of understanding, and in this way details, such as the sound effect described above, will be discovered to have been carefully designed and not merely arranged by accident. De Quincey goes on to provide further opportunity for such surrender or submission by the reader in his exploitation of similar sonic design.

The knocking device reappears in the murder essays. However, in this case it is presented with footsteps and breathing to develop an intimately detailed listening experience which results in a psychological realism that is truly cinematic (or perhaps novelistic). Preceding the extract below - which appears in the 'Postscript to the Supplementary Paper on Murder Considered as One of the Fine Arts' (2006/1827, pp. 109-111) - the murderer, Mr Williams, has performed his 'work of extermination' within the house at No. 29, in Ratcliffe Highway, London, and is interrupted by the return from an errand of the maid Mary who knocks at the door and upon receiving no response is overcome by apprehension. She knocks again and the following detailed sound score produces both Mary and the reader as a listening subjectivity:

To pause, therefore, to impose stern silence upon herself, so as to leave room for the possible answer to this final appeal, became a duty of spasmodic effort. Listen, therefore, poor trembling heart; listen, and for twenty seconds be still as death. Still as death she was: and during that dreadful stillness, when she hushed her breath that she might listen occurred an incident of killing fear, that to her dying day would never cease to renew its echoes in her ear. She, Mary, the poor trembling girl, checking and overruling herself by a final effort, that she might leave full opening for her dear young mistress's answer to her own last frantic appeal, heard at last and most distinctly a sound within the house. Yes, now beyond a doubt there is coming an answer to her summons. What was it? On the stairs, not the stairs that led downwards to the kitchen, but the stairs that led upwards to the single storey of bedchambers above, was heard a creaking sound. Next was heard most distinctly a footfall: one, two, three, four, five stairs were slowly and distinctly descended. Then the dreadful footsteps were heard advancing along the little narrow passage to the door. The 
steps-oh heavens! whose steps?-have paused at the door. The very breathing can be beard of that dreadful being, who has silenced all breathing except his own in the house. There is but a door between him and Mary. What is he doing on the other side of the door? A cautious step, a stealthy step it was that came down the stairs, then paced along the little narrow passage - narrow as a coffin - till at last the step pauses at the door. How hard the fellow breathes! He, the solitary murderer, is on one side the door, Mary is on the other.

In this sequence the sounds of footsteps and breathing are amplified by concentrated listening, much as they would be in the foley track of a film sequence. De Quincey carefully constructs the two correlates, subjective and objective, of the sound phenomena which collapse into a series of sound effects. At one end of the relation is the focused, forensic attention and questioning imagination that constructs the detailed architectural image of the interior of the house and the image of the heavy-breathing intruder that occupies it; and at the other the materiality of the events from which the sounds arise: the creaking stair, the enumerated footfalls made spatially distinct by the reverberation, occlusion and diffraction effects of the architectural features of the house. Here de Quincey provides us with fully realised and complete, paradigmatic sound effects.

\section{The sigh, the solemn wind and the sonic palimpsest}

In 'Suspiria de Profundis' (1985/1845) de Quincey develops the carefully worked out sound effect of the sigh. This essay expands upon the mention of an autobiographical 'passage in childhood' made in the 'Confessions'. This tendency in de Quincey's writings to refer back or forward in time to events or previously written material or literary references is characteristic of both his written style and - as he attempts to explain in a section of this essay entitled 'The Palimpsest' (p. 139) - his cognitive style. In this essay the palimpsest is explained in historical terms based on the imperfect erasure and reuse of parchment before the invention of the printing press. The result of this reuse is that ideas and images reappear in the writing under the text 'super-scribed', making strange connections between ages. The parallel between this idea and the more contemporary form of the hypertext is obvious. De Quincey develops this idea by demonstrating the ebb and flow of ideas throughout the ages determined by the prejudices of each. He explains that 'what once had been hot-house plants [...] now were held to be weeds', what 'should be sense for your own generation, nonsense for the next, should revive into sense for the next after that, but again become nonsense for the fourth; and so on by alternate successions'. This idea of overlaid images is for de Quincey a characteristic of human cognition, for as he states: 'what else than a mighty and natural palimpsest is the human brain, ... everlasting layers of ideas, images, feelings, have fallen upon your brain as softly 
as light. Each succession has seemed to bury all that went before. And yet in reality not one has been extinguished' (p. 144). This overlaying is revealed or exposed in the sonic effect known as anamnesis (Augoyard \& Torgue, 2005, p. 21), referred to earlier in relation to a drug-induced musical reverie, 'in which a past situation or atmosphere is brought back to the listener's consciousness [...] reconnecting past mental images to present consciousness, with no will other than the free activity of association'. Torgue's presentation of the effect aptly captures de Quincey's sense of the palimpsest that is 'characterized principally by a temporal shift [and] anamnesis can also combine spatial and cultural shifts'.

Having introduced the idea of the palimpsest de Quincey finally returns to the morbid principal sound effect of an essay littered with ideas about sound. His focus is the profound reverie and subsequent anamnesis resulting from hearing the sound a 'solemn wind' blowing on a summer's day. This sound, for de Quincey, becomes 'the one sole audible symbol of eternity'. He states that 'three times in my life I have happened to hear the same sound when standing between an open window and a dead body on a summer day' (pp. 104-105). He describes the initial experience that occurred as a child on the death of a much loved sister. On entering the room alone in which her dead body lay he is confused by the incomprehensible combination of vigorous, bright sunshine and the lifelessness of the corpse. This is a "perplexed [...] compound experience' (which I referred to below) that becomes attached in his memory to a solemn wind: 'the most mournful that ever I heard [...] a wind that had swept the fields of mortality for a hundred centuries'. De Quincey continues by describing and expanding on the resulting intense reverie replete with religious and literary images, transformations of space and time. De Quincey acknowledges and contributes to the construction of this quintessentially romantic metaphor (Abrams, 1957) of 'nature's [aeolian] music'. However, in addition to this broader cultural resonance, for de Quincey the effect is more personal in that it is presented as a formative childhood experience that impacts on his career as an author and a drug addict. In this respect, de Quincey's 'sigh from the deep' conforms to several aspects of Torgue's definition of the anamnesis effect as it links adult and childhood experience, and 'although it is essentially subjective, anamnesis also has an archetypal dimension. Specific sounds can produce common references for a given culture: sounds of flowing water, [for example]. There are many shared backgrounds over which individual perceptions are laid' $(2005$, p. 23). Thus, the sonic effect and the auditory sensibility on which it is built are part of the circulation of sense that the language of sound and the 'language of things' comprise (Merleau-Ponty, 1973, p. 7; 2002/1945, p. 322; Schaeffer, 1966, p. 337). 


\section{Sensory fusion and sonic effects}

De Quincey's understanding of this language of things ${ }^{10}$ is careful to avoid a simple division of the senses, and in this essay, as elsewhere, the image he develops is a 'multi-modal' image which combines the entire sensorium, including the auditory and the visual and only occasionally the conceptual, for as he asserts, 'far more of our deepest thoughts and feelings pass to us through perplexed combinations of concrete objects, pass to us as involutes in compound experiences incapable of being disentangled, than ever reach us directly, and in their own abstract shapes' (p. 104). Here de Quincey extends his critical view of the understanding and provides support for the idea of a con-fusion or folding-in or wrapping-around in an involution of object-images. Presumably the direct abstract apprehension of things through the combination of concepts and intuition or sensation in the Kantian model results in clearly separated sensory object categories or secondary properties such as shapes or sounds. The more profound impact or effect of 'our deepest thought or feelings' by-passes the understanding. This assertion for the power of the concrete over the abstract echoes the intuitions of Pierre Schaeffer, father of the musique concrete movement (Chion, 1983/2009, p. 37).

Further evidence of this attitude to sensory fusion is provided in an instructive literary diversion intended to disabuse the reader of any intention de Quincey may appear to have to create satire from the strange collisions of images he proposes. Of this potential for laughter he says: 'if laughter had been possible, it would have been such laughter as oftentimes is thrown off from the fields of ocean: laughter that bides, or that seems to evade mustering tumult; foam-bells that weave garlands of phosphoric radiance for one moment round the eddies of gleaming abysses; mimicries of earth-born flowers that for the eye raise phantoms of gaiety, as oftentimes for the ear they raise the echoes of fugitive laughter, mixing with the ravings and choir voice of an angry sea'. In a footnote we are instructed that the origin of this poetic image is in Aeschylus's Prometheus Bound: 'Oh multitudinous laughter of the ocean billows' of which de Quincey states: 'It is not clear whether Aeschylus contemplated the laughter as addressing the ear or the eye' (1985/1845, p. 144). What is clear is that in de Quincey's reading of Aeschylus and in the image of laughter he creates from it he is certainly addressing both, and that in the poetic image and the sense of the sonic effect of metamorphosis (Chelkoff, 2005) he integrates the entire sensorium.

\section{Conclusion}

De Quincey uses sound extensively throughout his writing as a literary and descriptive device, and this article has barely scratched the surface of de Quincey's sonic 
riches. In many ways de Quincey's sonic imagination prefigures the horizon and focus of subsequent sound design in audiovisual media, particularly in crime drama. However, it is the ontological and epistemological insights that arise from his presentation and the application and analysis of the theory of sonic effects that are predominantly taken up in this reading. In each of the examples shown above - reflections on music, knocking in Macbeth and the Williams murders, and the sigh/wind anamnesis - de Quincey elaborates not merely on their effect on consciousness, but as effects in their own right. This view of an effect as a structure of experience that is neither causally prior nor subsequent, neither purely objective nor subjective, but that can be manipulated and realised in literature, the media or the environment is both amply demonstrated by de Quincey and provides a powerful tool for understanding sound within his writing and beyond. Ultimately, it was de Quincey's presentation of the imagination and the power of dreaming and through his discursive writing style - the representation of a uniquely de Quincian expansive cognitive style ${ }^{11}$ (Lancashire, 2004), that became the focus of the sound design for the creative project in which this research was undertaken. De Quincey's creation of atmospheres and atmospheric effects and the challenge of negotiating the sense of his highly mannered style were also key factors in the design, as was de Quincey's deconstruction of the listening subject and associated shifts in perspective. Each of these factors is consistent with the innovative acoustemology that underlies the de Quincian soundtrack.

\section{References}

Abrams, M.H. (1957). The Correspondent Breeze: A Romantic Metaphor. The Kenyon Review, 19(1), 113130.

Augoyard, J.F., \& Torgue, H. (2005). Sonic experience: a guide to everyday sounds. Translated by A. McCartney \& D. Paquette. Montreal: McGill-Queen's University Press.

Chelkoff, G. (2005). Metamorphosis. Translated by A. McCartney \& D. Paquette. In: Augoyard, J. F., \& Torgue, H. (Eds.), Sonic experience: a guide to everyday sounds (pp. 73-77). Montreal: McGill-Queen's University Press.

Chion, M. (1983/2009). Guide To Sound Objects. Pierre Schaeffer and Musical Research http://www.ears. dmu.ac.uk/spip.php?page=articleEars\&id_article=3597.

Coleridge, S.T. (1984/1817). The collected works of Samuel Taylor Coleridge, Volume 7: Biographia Literaria. Princeton: Princeton University Press.

Colwell, C. (1997). Deleuze and Foucault: Series, Event, Genealogy. Theory \& Event, 1(2).

De Quincey Co. (2009). Ghost Quarters [performance]. 9-16 May 2009, Carriageworks, Sydney.

De Quincey, T.D., \& Morrison, R. (2006). On murder. Oxford: Oxford University Press.

De Quincey, T.D. (1985/1821). Confessions of an English Opium Eater. In: Lindop, G. (Ed.), Confessions of an English opium-eater and other writings (pp. 1-80). Oxford: Oxford University Press.

De Quincey, T.D. (1985/1823). On the Knocking at the Gate in Macbeth. In: Lindop, G. (Ed.), Confessions of an English opium-eater and other writings (pp. 81-86). Oxford: Oxford University Press. 
De Quincey, T.D. (1985/1845). Suspiria de Profundis. In: Lindop, G. (Ed.), Confessions of an English opiumeater and other writings (pp. 87-182). Oxford: Oxford University Press.

De Quincey, T.D. (2003). The Works of Thomas De Quincey. London: Pickering \& Chatto.

De Quincey, T.D. (2006/1827). Postscript to the Supplementary Paper on Murder Considered as One of the Fine Arts. In: Morrison, R. (Ed.), On murder (pp. 95-142). Oxford: Oxford University Press.

Deleuze, G. (1968/1994). Difference and repetition. Translated by P. Patton. London: Athlone Press.

Deleuze, G. (1969/2004). The logic of sense. Translated by M. Lester, C.V. Boundas \& C.J. Stivale. New edition. London: Continuum.

effect, n. (2011) Oxford English Dictionary Online: Oxford University Press. http://www.oed.com.

Feld, S. (2003). A Rainforest Acoustemology. In: Bull, M., \& Back, L. (Eds.), The auditory culture reader (pp. 223-239). New York: Berg.

Folkerth, W. (2002). The sound of Shakespeare. London: Routledge.

Hanslick, E. (1957/1854). The Beautiful in Music. Translated by G. Cohen. New York: The Liberal Arts Press.

Kant, I. (1787/1929). Immanuel Kant's Critique of pure reason. Translated by N.K. Smith. London: Macmillan.

Lancashire, I. (2004). Cognitive Stylistics and the Literary Imagination. In: Schreibman, S., Siemens, R., \& Unsworth, J. (Eds.), A Companion to Digital Humanities. Oxford: Blackwell. http://www.digitalhumanities.org/companion/.

Lindop, G. (1985). Introduction. In: Lindop, G. (Ed.), Confessions of an English opium-eater and other writings (pp. 81-86). Oxford: Oxford University Press.

Merleau-Ponty, M. (1973). The Prose of the World. Evanston: Northwestern University Press.

Merleau-Ponty, M. (2002/1945). Phenomenology of perception. London: Routledge.

Schaeffer, P. (1966). Traite des objets musicaux: essai interdisciplines (Unpublished, translated by J. Dack \& C. North). Paris: Editions du Seuil.

Torgue, H. (2005). Anamnesis. Translated by A. McCartney \& D. Paquette. In: Augoyard, J.F., \& Torgue, H. (Eds.), Sonic experience: a guide to everyday sounds (pp. 21-25). Montreal: McGill-Queen's University Press.

\section{Notes}

1 Perhaps mainly through the exigency of journalistic reuse, but also as a sort of literary palimpsest as proposed in 'Suspiria'.

2 He makes the typically self-deprecating observation that once he had overcome the worst of his addiction 'my brain performed its function as healthily as ever before: I read Kant again; and again I understood him, or fancied that I did'. Six essays based on his readings of and about Kant appear in the 21 volume complete works (de Quincey, 2003). For use of the terms matter and form see Kant's 'Critique of Pure Reason' (1787/1929, A20/B34).

3 Prefiguring Edward Hanslick (1957/1854).

4 This creative production of sound images is referred to as phonomnesis by Augoyard (2005, p. 85).

5 It is important to note here that a named effect points to or refers to an independent concrete entity rather than an abstracted notion of effect as a result of a cause. This point is made by Deleuze in his definition of effect $(1968 / 1994,228)$.

6 As Merleau-Ponty points out, examples of phenomenological thinking arise at diverse points in history (2002/1945, p. viii).

7 Perhaps following Coleridge's analysis of primary and secondary imagination in his Biographia Literaria (Coleridge, 1984/1817, p. xxxix). 
8 In this case conjugation appears to work in both directions rather than relying on the temporal precedence of a particular cause. See the 'Second Series of Paradoxes of Surface Effects' in The Logic of Sense (Deleuze, 1969/2004, p. 8).

9 For a useful discussion of the relationship of series of events, effects and states of affairs in the work of Deleuze see Colwell (1997).

10 Once again prefiguring Merleau-Ponty.

11 Note that work on cognitive stylistics seems to be based on models of speech production rather than acknowledging the augmentation of cognition by the written word both in production and reception. 